\title{
Assessment of the Water Quality Standard of Brahmani River in terms of Physico-Chemical Parameters
}

\author{
Swati Kanungo ${ }^{1}$, Nirmal Kumar Bhuyan ${ }^{2}$ and Hemanta Kumar Patra ${ }^{3}$ \\ ${ }^{1 \& 3}$ Department of Botany, Utkal University, Bhubaneswar -,751007 \\ ${ }^{2}$ Water Quality Laboratory, Central Water Commission, Bhubaneswar - 751022
}

\begin{abstract}
The present investigation is aimed at assessing the current water quality standard along the stretch of Brahmani river in terms of physico-chemical parameters. In the selected study area, river Brahmani is receiving a considerable amount of industrial wastes and witnessing a considerable amount of human and agricultural activities .Nine samples were collected along the entire stretches of the river basin during the period from September-2013 to August-2014 on the first working day of every month. Various physico-chemical parameters like $\mathrm{pH}, \mathrm{EC}$, total hardness, total alkalinity sodium, potassium, calcium, magnesium, nitrate, sulphate D.O., B.O.D. etc. were analyzed. The present study indicates that the water quality of Brahmani river is well within tolerance limit taking the physico-chemical parameters into considerations.
\end{abstract}

Key Words: Brahmani river, Physico-chemical parameters, pH ,EC, Total hardness, D.O, B.O.D.

\section{Introduction}

As water is the basic need of the habitants, its safeness must be studied before use. The present study aims at detecting the quality of water across the Brahmani river in respect of physico-chemical and bacteriological parameters. Although in rural areas of developing countries, majority of water quality problems are related to bacteriological and other biological contaminations, a significant number of very serious problems may also occur as a result of physicochemical impurity of water resources. With rapid industrialization and urbanization, the river water pollution is increasing rapidly. Effect of poor water quality on human health was noted for the first time in 1854 by John Snow, when he traced the outbreak of cholera epidemic in London to the Thames river water which was grossly polluted with raw sewage. Since then, the science of water quality monitoring has progressed. In the third world countries $80 \%$ of all diseases are directly related to poor drinking water and insanitary conditions. The physico-chemical quality of river water is very important from the health point of view. Thus, constant monitoring of river water quality is needed so as to record any alteration in quality and outbreak of health disorders. The present study reports on the river water quality of nine different stations of Brahmani basin as given below. The present study aims at detecting the quality of water in respect of physico-chemical parameters studies. The possible number of such parameters necessary to completely specify the quality of water are very large. However, at present fourteen parameters are considered to characterize the Brahmani river water.

\section{Study Area}

River Brahmani, the second largest river of Odisha is one of the major peninsular river systems in India. The confluence of the rivers Koel and Sankh at Vedvyasa near Rourkela in the district of Sundargarh gives rise to the river Brahmani. It travels southward through the districts of Sundargarh, Deogarh, Angul, Dhenkanal, Jajpur, and Kendrapara finally flowing into Bay of Bengal. After Jenapur, it divides into two rivers namely Brahmani and Kharasrota (Kharasuan). The major flow of water goes into Kharasrota. After covering a few kilometers, the river Birupa joins Brahmani and it flows onwards in the name of Brahmani though its major portion of water comes from the river Birupa. The study area covers nine major sampling points covering Sankh at Tilga, Koel at Jareikela and Brahmani river from its origin at Vedvyasa near Panposh up to Jenapur. In this stretch, the river Brahmani is joined by several drains and streams carrying industrial effluents, city wastages, mining residues etc. along with a number of tributaries. Jenapur is the last sampling point. 
Table: 1

\begin{tabular}{|c|c|c|c|c|l|}
\hline $\begin{array}{c}\text { Sample } \\
\text { Code }\end{array}$ & $\begin{array}{c}\text { Name of } \\
\text { the station }\end{array}$ & $\begin{array}{c}\text { River/ } \\
\text { Tributary }\end{array}$ & State & District & \multicolumn{1}{|c|}{ Description of the location } \\
\hline $\mathrm{S}_{1}$ & Tilga & Sankh & Jharkhand & Simdega & Upstream of Panposh \\
\hline $\mathrm{S}_{2}$ & Jaraikela & Koel & Odisha & & Upstream of Panposh \\
\hline $\mathrm{S}_{3}$ & Panposh & Brahmani & Odisha & Sundergarh & Confluence of Koel and Sankh to form Brahmani \\
\hline $\mathrm{S}_{4}$ & $\begin{array}{c}\text { Tarkera } \\
\text { (R S P) }\end{array}$ & Brahmani & Odisha & Sundergarh & $\begin{array}{l}\text { Mixing point of Rourkela Steel Plant Effluent with } \\
\text { Brahmani }\end{array}$ \\
\hline $\mathrm{S}_{5}$ & Gomlai & Brahmani & Odisha & Sundergarh & About 50 km down stream of Rourkela \\
\hline $\mathrm{S}_{6}$ & Talcher & Brahmani & Odisha & Sundergarh & $\begin{array}{l}\text { About } 5 \text { km upstream of the Nalco effluent confluence } \\
\text { with Brahmani }\end{array}$ \\
\hline $\mathrm{S}_{7}$ & Nandira & Brahmani & Odisha & Sundergarh & confluence of Nalco effluent with Brahmani \\
\hline $\mathrm{S}_{8}$ & Kamalanga & Brahmani & Odisha & Sundergarh & $\begin{array}{l}\text { 1.5 km down stream of the confluence of Nalco effluent } \\
\text { with Brahmani }\end{array}$ \\
\hline $\mathrm{S}_{9}$ & Jenapur & Brahmani & Odisha & Jajpur & Before the bifurcation of Brahmani to form Kharasrota \\
\hline
\end{tabular}

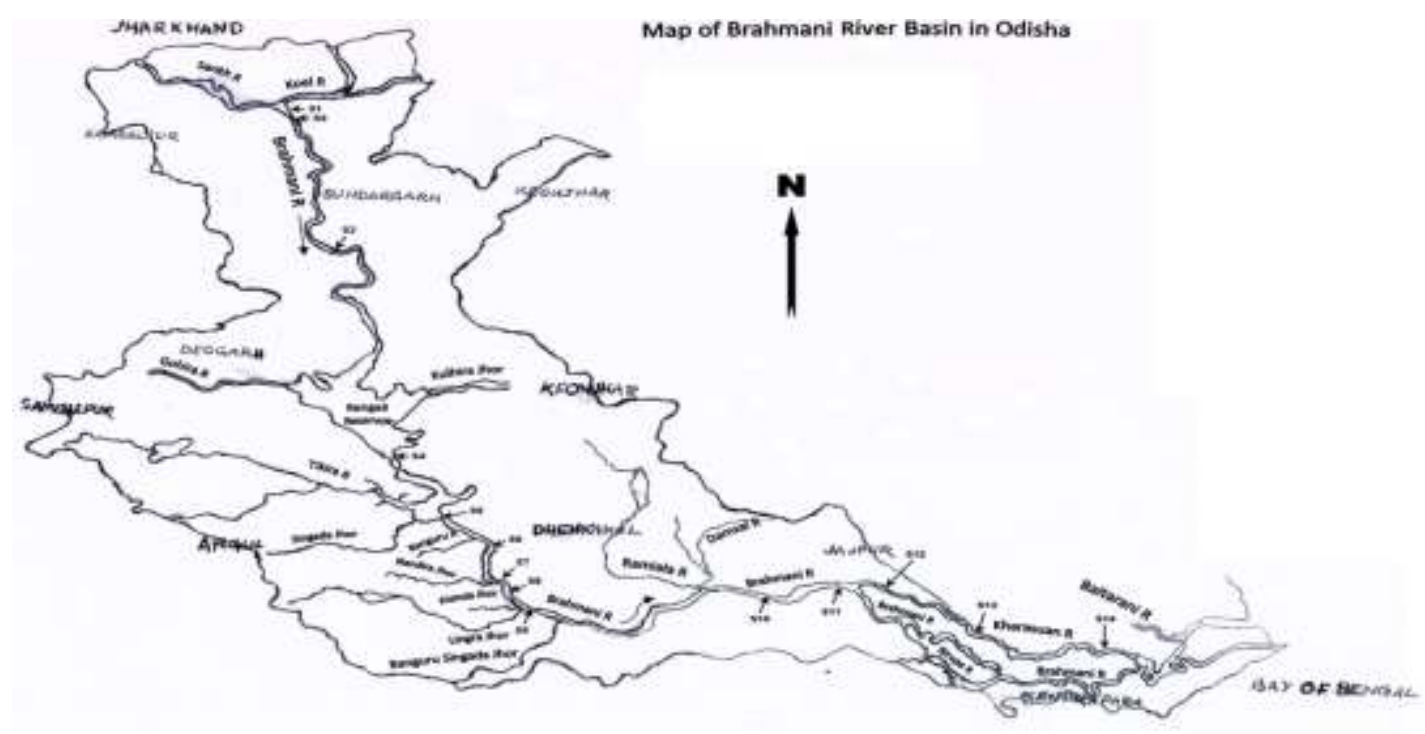

\section{Materials And Methods}

Water samples were collected every month, from September 2013 to August 2014 from nine different stations as mentioned in the above table, in clean and dry polythene bottles. The water samples were collected and preserved for testing of various parameters at $10^{\circ} \mathrm{C}$ throughout the period of chemical analysis.

The $\mathrm{pH}$ and dissolved oxygen of water samples were measured immediately after sampling at the field itself. Samples were subjected to filtration before chemical analysis. The determination of TDS was done by gravimetric process while the total hardness was carried out by EDTA complexometric titration method (APHA, 2005).The Winkler's alkali iodide-azide method was followed for the estimation of D.O. and B.O.D. Nitrate was determined by colorimetric procedure (APHA, 2005; Singh and Mohapatra,1998). Fecal coliform population was analyzed by MPN $/ 100 \mathrm{ml}$ method by growing on M-FC medium at temperature $44.5^{\circ} \mathrm{C}$ and counted after 48 hours.

\section{Results and Discussion}

TEMPERATURE: Temperature is an important factor to influence the physico-chemical parameters and the biological reaction in water. Higher values of temperature accelerate the chemical reaction and reduce the solubility of gases and dissolved oxygen. In the present study temperature varied from $22^{\circ} \mathrm{C}$ to $35^{\circ} \mathrm{C}$.

pH LEVEL: The pH of most raw water sources lies within the range of $6.5-8.5$ (Henery and Heinke, 2005). All the water samples are found to have $\mathrm{pH}$ value well within the tolerance limit. The $\mathrm{pH}$ value ranges from 6.5 to 8.4. Panposh recorded the maximum $\mathrm{pH}$ value 8.4 and Gomlai the minimum $\mathrm{pH}$ value 6.5.

ELECTRICAL CONDUCTIVITY: Pure water is a poor conductor of electricity. Presence of acids, bases and salts in water make it relatively good conductor of electricity. With increased air pollution, the acid rain also adds to the conductivity of surface water. Greater is the conductivity, greater anions and cations in water and greater is the 
dissolved matter (electrolyte) in it. Electrical conductivity is used as a basic index in judging the suitability of water for potable properties. Present studies revealed that all the samples recorded, had conductivity values well within the tolerance limit prescribed by WHO, 1984. Tarkera (R.S.P.) recorded the highest conductivity value $610 \mu \mathrm{mho} / \mathrm{cm}$. It may be due to the impact of Rourkela Steel Plant effluent. The minimum conductivity value $84 \mu \mathrm{mho} / \mathrm{cm}$ is recorded at Tilga. Tolerance limit for conductivity in drinking water is $2300 \mu \mathrm{mho} / \mathrm{cm}$.

TOTAL HARDNESS: Water hardness is the traditional measure of capacity of water to react with soap, hard water requiring a considerable amount of soap to produce lather. Scaling of hot water pipes, boilers and other household appliances is due to hard water. In fresh water, the principal hardness causing ions are calcium and magnesium; the ions strontium, iron, barium and manganese also contribute to some extent. It is expressed as an equivalent concentration of calcium carbonate. The permissible limit of hardness as calcium carbonate is $300 \mathrm{mg} / \mathrm{l}$. Our investigation shows all the water samples are much below the permissible limit. The total hardness is considered taking presence of calcium and magnesium ions in water samples. Its permissible limit is 75 to $200 \mathrm{mg} / \mathrm{l}$. Maximum value was recorded at Tarkera and minimum value at Gomlai.

TOTAL ALKALINITY: Alkalinity is not a pollutant. It is a total measure of the substances in water that have acid neutralizing capacity. Alkalinity indicates the power of a solution to react with acid and buffer its $\mathrm{pH}$, that is the power to restrict its $\mathrm{pH}$ from changing (Webber and Stamm , 1963). It is due to salts of weak acids and bicarbonates and is estimated in terms of an equivalent amount of calcium carbonate. No permissive and excessive values of total alkalinity are given by WHO, ISI and ICMR (PHSDWS, 1962). But according to USPHS, the value of total alkalinity as $\mathrm{CaCO}_{3}$ is $120 \mathrm{mg} / \mathrm{l}$. The average value of total alkalinity in the different sources of water samples of the present observation ranges from 40.00 at Tilga to $84.00 \mathrm{mg} / \mathrm{l}$ at Kamalanga. It indicates that the river water has better buffering capacity going down of the stream and is important for fish and aquatic life. It is also less vulnerable to acid rain. The alkalinity has no known adverse effect on health, some evidence has been given to indicate its role in heart disease (Goel, 1984).

TOTAL DISSOLVED SOLIDS : Total dissolved solids at a given temperature is the material residue left in the vessel after evaporation of a filtered sample and subsequent drying in an oven. TDS contains different kinds of nutrients and have been proved to be a very useful parameter. A sudden rise in TDS content can often indicate pollution by an extraneous source. Excess amount of TDS may disturb ecological balance and cause imbalance in osmotic regulation and suffocation in aquatic fauna even in presence of fair amount of dissolved oxygen(Webber and Stamm, 1963).

Water containing more than $500 \mathrm{mg} / \mathrm{l}$ of TDS is not considered desirable for drinking water supply and normally less palatable and may induce an unfavorable physiological reaction in the transient consumer. In the present investigation, it is seen that TDS value of most of the water samples are well within the permissible limit except at Jareikela. The increased TDS value in the lower stretches of the river may be due to the salt water intrusion due to the proximity to Bay of Bengal (Bhattacharya et al., 2008).

SODIUM AND POTASSIUM: Sodium is the chief cation in the extra cellular fluid. About $50 \%$ of body sodium is present in the bone, $40 \%$ in the extra cellular fluid and the remaining (10\%) in the soft tissues whereas potassium is the principal intracellular cation. It is equally important in the extra cellular fluid for specific function such as influencing cardiac muscle activity (Satyanarayan., 2004). According to European Economic Community the limit for sodium is $200 \mathrm{mg} / \mathrm{l}$ and for potassium is $10 \mathrm{mg} / \mathrm{l}$ of drinking water. The study reveals the mean value of sodium and potassium content in the water samples are well within the permissible limit along the entire stretch of Brahmani river.

DISSOLVED OXYGEN: Dissolved oxygen is one of the most important parameters of water quality assessment and reflects the physical and biological processes prevailing in the water and shows metabolic balance. A high D.O. level in a river water sample is good because it makes the water better for drinking as well as for bathing point of view and friendly for aquatic lives. However, high D.O. levels speed up corrosion in water pipes. For diverse fish population the D.O. level must range from $4-9 \mathrm{mg} / \mathrm{l}$. The river water of Brahmani is good fishing water. However, according to European Economic Community, the standard value of D.O. is $5 \mathrm{mg} / \mathrm{l}$ for drinking water. The average D.O. values of water samples from the river ranges from $5.6 \mathrm{mg} / \mathrm{l}$ to $7.5 \mathrm{mg} / \mathrm{l}$.

BIOCHEMICAL OXYGEN DEMAND : The degree of microbial mediated oxygen consumption in water is known as biochemical oxygen demand. This parameter is commonly measured by the quantity of oxygen utilized by suitable micro-organisms during 5 days period at $20^{\circ} \mathrm{C}$. It is not a pollutant but an indicator to what extent the water is polluted. Its value $6.0 \mathrm{mg} / \mathrm{l}$ or more in water body is said to be polluted. Present study reveals the mean value of B.O.D of the Brahmani river is $3.3 \mathrm{mg} / \mathrm{l}$ at Tarkera which is the highest average value whereas that of the remaining sampling stations ranges from $0.19 \mathrm{mg} / \mathrm{l}$ to $0.9 \mathrm{mg} / \mathrm{l}$. The B.O.D of Mahanadi, the biggest river of Odisha is of high 
mean value, $11.2 \mathrm{mg} / \mathrm{l}$ (Singh and Mohapatra., 1998) at Mahanadi-Atharabanki and Mahanadi sea confluence (Samantaray et al., 2009). Thus, the Brahmani river water is less polluted from B.O.D. point of view than Mahanadi.

BACTERIOLOGICAL PARAMETER : Pathogenic bacteria present in water are responsible for causing water borne diseases like cholera, typhoid, dysentery (bacillary and amoebic) etc. The bacteriological analysis of water is essential to determine its potability for drinking. The bacteriological analysis carried out were most probable number (MPN) of total coliform and fecal coliform. Presence of coliform bacteria is undesirable for human consumption. Generally, the coliform bacteria is observed in raw water samples. When the water comes in contact with sewage, coliform bacteria are observed. Occurrence of fecal coliform is more significant than total coliforms. According to WHO, E.coliform should be absent and if coliform counts were found, then in no case it should exceed 10/100 ml (WHO, 1984). The bacteriological analysis was done for all the samples during the year and found that the presence of fecal coliform was alarmingly high in Brahmani river particularly at Panposh. It is mainly due to high defecation of near by people in open places along the river bank and other human activities across the river stretch. The upper stretch of the river at Rourkela has a high MPN count,which is minimum at Rengali Samal stretch and again increases down stream.

Table:1

\begin{tabular}{|c|c|c|c|c|c|c|c|c|c|}
\hline \multirow{2}{*}{$\begin{array}{c}\text { Name of the } \\
\text { Sampling Station }\end{array}$} & \multicolumn{3}{|c|}{ pH } & \multicolumn{3}{|c|}{$\begin{array}{c}\text { Conductivity in } \\
\mu \mathrm{mho} / \mathrm{cm}\end{array}$} & \multicolumn{3}{|c|}{$\begin{array}{c}\left.\text { Sulphate(} \mathrm{SO}_{4}^{--}\right) \\
\text {in } \mathrm{mg} / \mathrm{l}\end{array}$} \\
\hline & Max & Min & Mean & Max & Min & Mean & Max & Min & Mean \\
\hline Tilga- $S_{1}$ & 7.9 & 7.3 & 7.6 & 126 & 84 & 104 & 37.1 & 1.3 & 9.4 \\
\hline Jareikela- $S_{2}$ & 8.0 & 7.2 & 7.6 & 330 & 157 & 222 & 36.2 & 1.2 & 8.3 \\
\hline Panposh-S $\mathrm{S}_{3}$ & 8.4 & 7.0 & 7.5 & 250 & 132 & 191 & 49.0 & 1.0 & 17.1 \\
\hline R.S.P.- $\mathrm{S}_{4}$ & 8.2 & 6.5 & 7.5 & 610 & 260 & 375 & 59.2 & 24.6 & 44.2 \\
\hline Gomlai-S $S_{5}$ & 8.0 & 6.8 & 7.6 & 280 & 102 & 196 & 53.0 & 4.1 & 19.8 \\
\hline Talcher- $\mathrm{S}_{6}$ & 8.0 & 7.1 & 7.6 & 171 & 105 & 137 & 198.7 & 2.8 & 27.1 \\
\hline Nandira-S ${ }_{7}$ & 7.8 & 7.3 & 7.5 & 490 & 132 & 310 & 78.4 & 15.0 & 43.1 \\
\hline Kamalanga- $\mathrm{S}_{8}$ & 7.9 & 7.2 & 7.6 & 470 & 125 & 281 & 204.8 & 13.8 & 53.2 \\
\hline Jenapur- $\mathrm{S}_{9}$ & 7.9 & 7.0 & 7.6 & 190 & 120 & 142 & 56.8 & 3.2 & 14.9 \\
\hline
\end{tabular}

Table:2

\begin{tabular}{|c|c|c|c|c|c|c|c|c|c|}
\hline \multirow{2}{*}{$\begin{array}{c}\text { Name of the } \\
\text { Sampling Station }\end{array}$} & \multicolumn{3}{|c|}{$\begin{array}{c}\text { Nitrate }\left(\mathrm{NO}_{3}{ }^{-}\right) \\
\text {in } \mathrm{mg} / \mathrm{L}\end{array}$} & \multicolumn{3}{|c|}{$\begin{array}{c}\text { Chloride }\left(\mathrm{Cl}^{-}\right) \\
\text {in } \mathrm{mg} / \mathrm{L}\end{array}$} & \multicolumn{3}{|c|}{$\begin{array}{c}\text { Bicarbonate }\left(\mathrm{HCO}_{3}^{-}\right) \text {in } \\
\mathrm{mg} / \mathrm{L}\end{array}$} \\
\hline & Max & Min & Mean & Max & Min & Mean & Max & Min & Mean \\
\hline Tilga- $S_{1}$ & 0.84 & 0.70 & 0.73 & 21.4 & 9.4 & 14.9 & 90 & 23 & 40 \\
\hline Jareikela- $S_{2}$ & 9.53 & 0.78 & 2.64 & 30.2 & 11.3 & 19.9 & 107 & 11 & 66 \\
\hline Panposh-S $\mathrm{S}_{3}$ & 0.71 & 0.70 & 0.71 & 22.6 & 11.3 & 16.2 & 102 & 28 & 75 \\
\hline R.S.P.- $\mathrm{S}_{4}$ & 1.22 & 0.76 & 1.07 & 50.9 & 22.6 & 33.7 & 209 & 11 & 77 \\
\hline Gomlai-S $S_{5}$ & 0.71 & 0.21 & 0.66 & 34.0 & 11.3 & 17.6 & 113 & 39 & 73 \\
\hline Talcher- $\mathrm{S}_{6}$ & 0.71 & 0.70 & 0.71 & 34.0 & 9.4 & 16.2 & 124 & 34 & 67 \\
\hline Nandira-S & 1.22 & 0.80 & 0.88 & 41.2 & 11.3 & 25.4 & 175 & 39 & 83 \\
\hline Kamalanga- $\mathrm{S}_{8}$ & 9.63 & 0.73 & 1.56 & 34.0 & 11.3 & 22.2 & 135 & 34 & 84 \\
\hline Jenapur- $S_{9}$ & 0.71 & 0.70 & 0.71 & 18.9 & 9.4 & 13.2 & 141 & 34 & 62 \\
\hline
\end{tabular}


Table:3

\begin{tabular}{|c|c|c|c|c|c|c|c|l|l|}
\hline \multirow{2}{*}{$\begin{array}{c}\text { Name of the } \\
\text { Sampling Station }\end{array}$} & \multicolumn{3}{|c|}{$\begin{array}{c}\text { Calcium(Ca } \\
\text { in mg/L }\end{array}$} & \multicolumn{3}{c|}{$\begin{array}{c}\text { Magnesium(Mg } \\
\text { in mg/L }\end{array}$} & \multicolumn{3}{c|}{$\begin{array}{c}\text { Faecal Coliform } \\
\text { MPN/100mL }\end{array}$} \\
\cline { 2 - 11 } & Max & Min & Mean & Max & Min & Mean & Max & Min & Mean \\
\hline Tilga-S & 13 & 6 & 10 & 3.9 & 1.0 & 2.4 & 7000 & 320 & 1510 \\
\hline Jareikela-S & 27 & 11 & 19 & 10.7 & 2.9 & 7.6 & 6300 & 110 & 1270 \\
\hline Panposh-S & 30 & 6 & 19 & 10.7 & 1.0 & 5.6 & 19500 & 14200 & 18100 \\
\hline R.S.P.-S & 42 & 14 & 30 & 26.2 & 1.9 & 11.4 & 18000 & 7300 & 9260 \\
\hline Gomlai-S & 24 & 10 & 18 & 28.2 & 2.9 & 10.4 & 3200 & 180 & 1120 \\
\hline Talcher-S & 53 & 10 & 20 & 14.6 & 3.9 & 7.3 & 7200 & 560 & 1740 \\
\hline Nandira-S & 38 & 13 & 26 & 30.1 & 1.9 & 10.6 & 8300 & 1300 & 2230 \\
\hline Kamalanga-S & 50 & 11 & 26 & 36.0 & 3.9 & 10.2 & 5840 & 1100 & 2120 \\
\hline Jenapur-S & 34 & 14 & 18 & 38.9 & 1.9 & 10.4 & 6540 & 1040 & 1800 \\
\hline
\end{tabular}

Table:4

\begin{tabular}{|c|c|c|c|c|c|c|c|c|c|}
\hline \multirow{2}{*}{$\begin{array}{c}\text { Name of the } \\
\text { Sampling Station }\end{array}$} & \multicolumn{3}{|c|}{$\begin{array}{l}\text { Sodium }\left(\mathrm{Na}^{+}\right) \\
\text {in } \mathrm{mg} / \mathrm{L}\end{array}$} & \multicolumn{3}{|c|}{$\begin{array}{c}\text { Potassium }\left(K^{+}\right) \\
\text {in } \mathrm{mg} / \mathrm{L}\end{array}$} & \multicolumn{3}{|c|}{ Total Solids } \\
\hline & Max & Min & Mean & Max & Min & Mean & Max & Min & Mean \\
\hline Tilga-S $S_{1}$ & 16.3 & 1.4 & 5.8 & 2.4 & 1.1 & 1.6 & 303 & 140 & 197.8 \\
\hline Jareikela-S $S_{2}$ & 15.3 & 2.4 & 8 & 8.1 & 1.4 & 3.7 & 594 & 250 & 392 \\
\hline Panposh-S $\mathrm{S}_{3}$ & 9.3 & 1.4 & 6 & 2.3 & 1.2 & 1.8 & 392 & 121 & 210.9 \\
\hline R.S.P.-S 4 & 23.0 & 2.8 & 13.5 & 8.0 & 1.4 & 5.1 & 410 & 100 & 160.5 \\
\hline Gomlai-S $_{5}$ & 12.1 & 3.0 & 7.5 & 3.0 & 1.6 & 2.2 & 350 & 116 & 177.7 \\
\hline Talcher-S 6 & 5.9 & 3.6 & 4.8 & 2.0 & 1.1 & 1.6 & 342 & 106 & 167 \\
\hline Nandira-S $S_{7}$ & 24.3 & 5.1 & 14.5 & 6.4 & 1.6 & 3.1 & 348 & 132 & 260.3 \\
\hline Kamalanga- $\mathrm{S}_{8}$ & 25.2 & 4.1 & 12.5 & 4.9 & 1.5 & 2.8 & 385 & 124 & 267.9 \\
\hline Jenapur- $S_{9}$ & 10.8 & 3.9 & 5.6 & 11.6 & 1.2 & 2.3 & 348 & 129 & 253.2 \\
\hline
\end{tabular}

Table:5

\begin{tabular}{|c|c|c|c|c|c|c|}
\hline \multirow{2}{*}{$\begin{array}{c}\text { Name of the Sampling } \\
\text { Station }\end{array}$} & \multicolumn{3}{|c|}{$\begin{array}{c}\text { D.O } \\
\text { in mg/L }\end{array}$} & \multicolumn{2}{c|}{ B.O.D } \\
in mg/L
\end{tabular}


Figure 1 :- pH

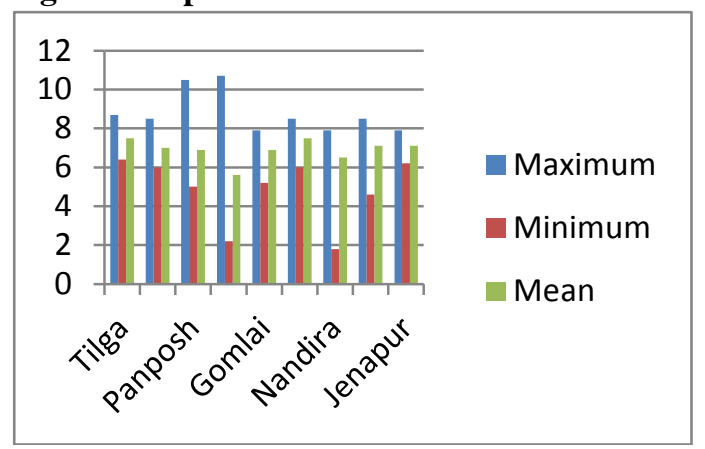

Figure 3:- Sulphate($\left(\mathrm{SO}_{4}^{--}\right)$in $\mathrm{mg} / \mathrm{L}$

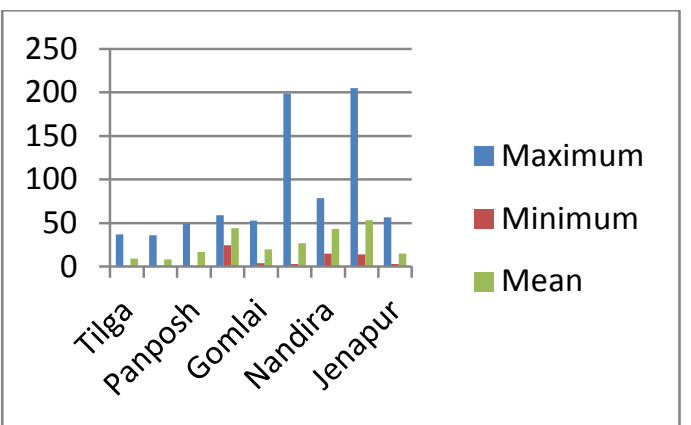

Figure 5:- Chloride(Cl $\left.{ }^{-}\right)$in $\mathrm{mg} / \mathrm{L}$

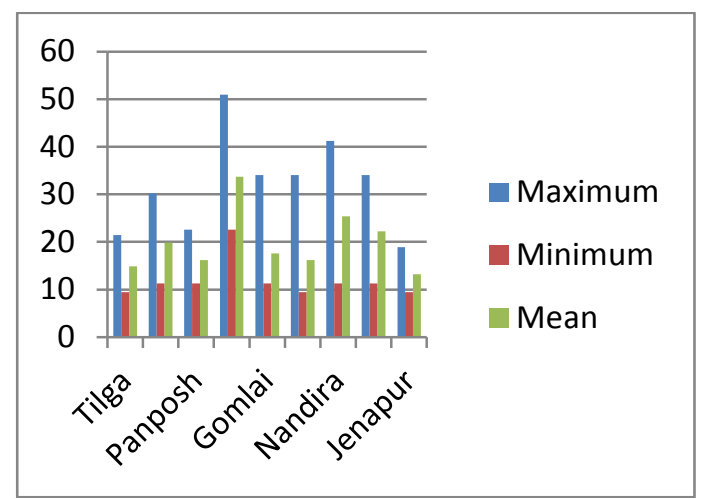

Figure 7:- Calcium $\left(\mathrm{Ca}^{++}\right)$in $\mathrm{mg} / \mathrm{L}$

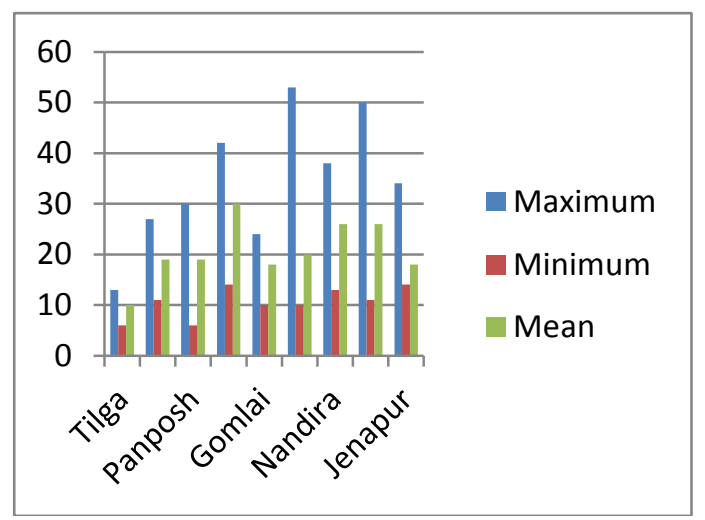

Figure 9:- Faecal Coliform MPN/100mL
Figure 2 :- Conductivity in $\mu \mathrm{mho} / \mathrm{cm}$

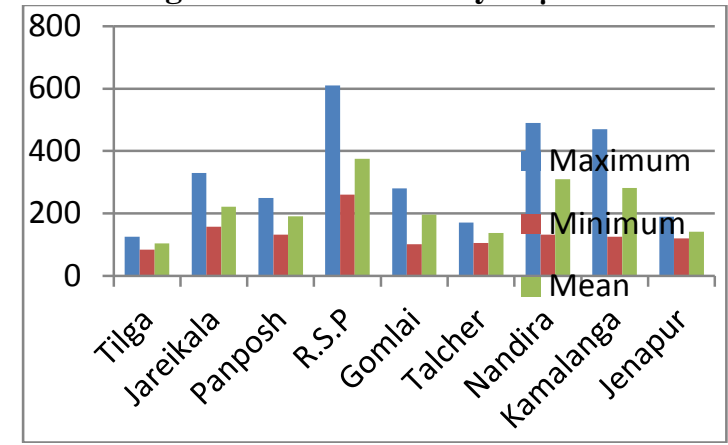

Figure 4:- Nitrate( $\left.\mathrm{NO}_{3}^{-}\right)$in $\mathrm{mg} / \mathrm{L}$

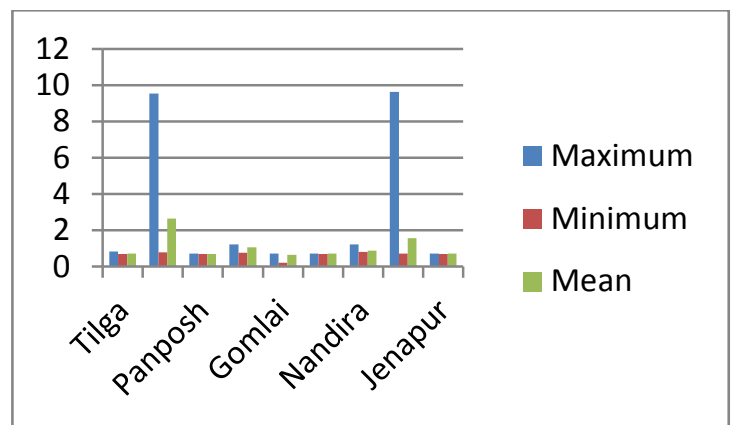

Figure 6:- Bicarbonate $\left(\mathrm{HCO}_{3}{ }^{-}\right)$in $\mathrm{mg} / \mathrm{L}$

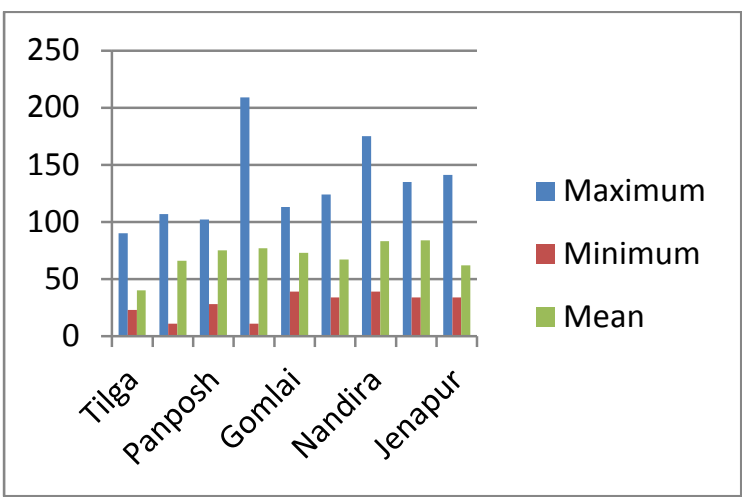

Figure 7 :- Magnesium $\left(\mathrm{Mg}^{++}\right)$in $\mathrm{mg} / \mathrm{L}$

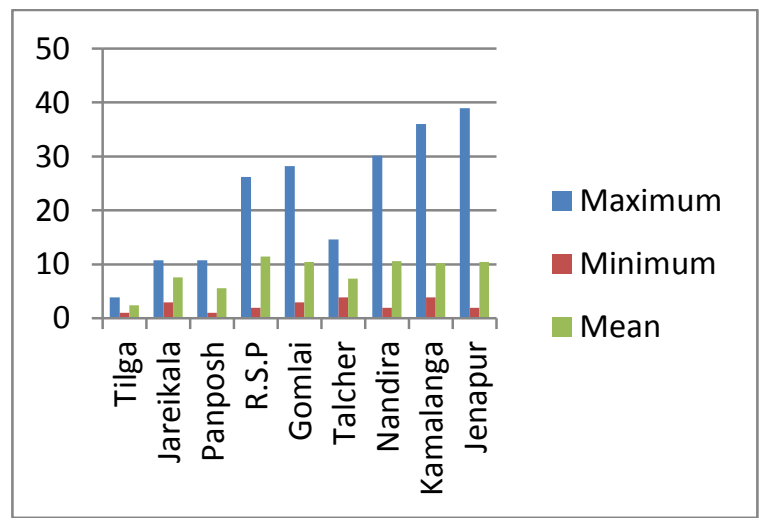

Figure 10:- Sodium $\left(\mathrm{Na}^{+}\right)$in $\mathrm{mg} / \mathrm{L}$ 


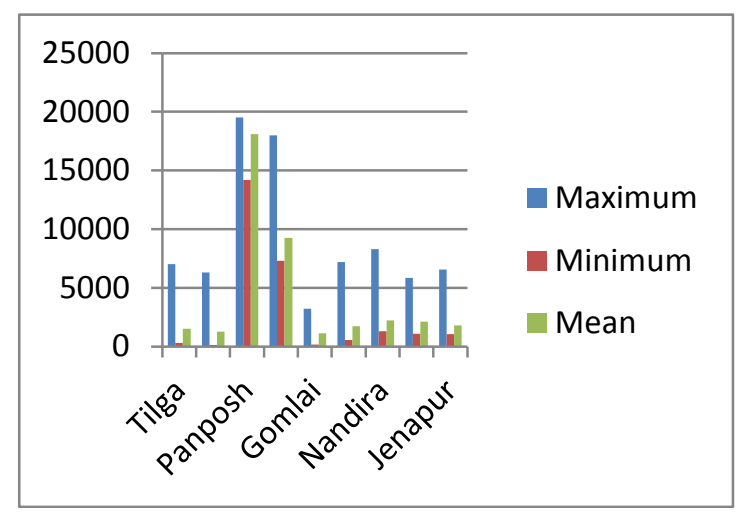

Figure 11:- Potassium $\left(\mathrm{K}^{+}\right)$in $\mathrm{mg} / \mathrm{L}$

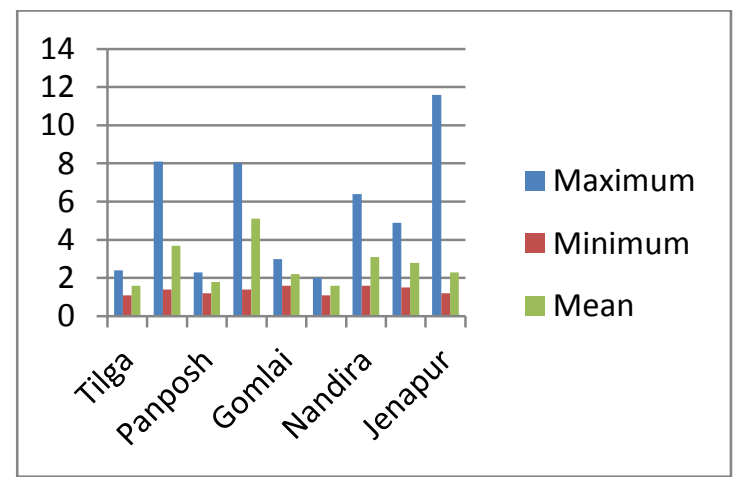

Figure 13:- D.O in mg/L

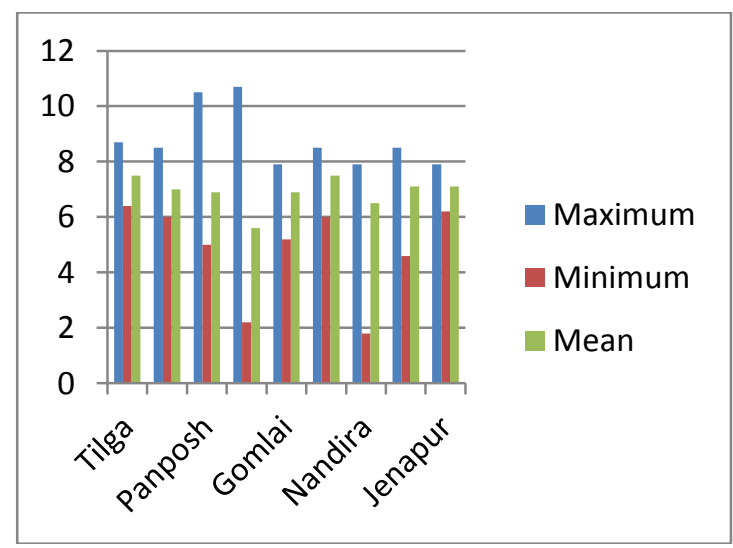

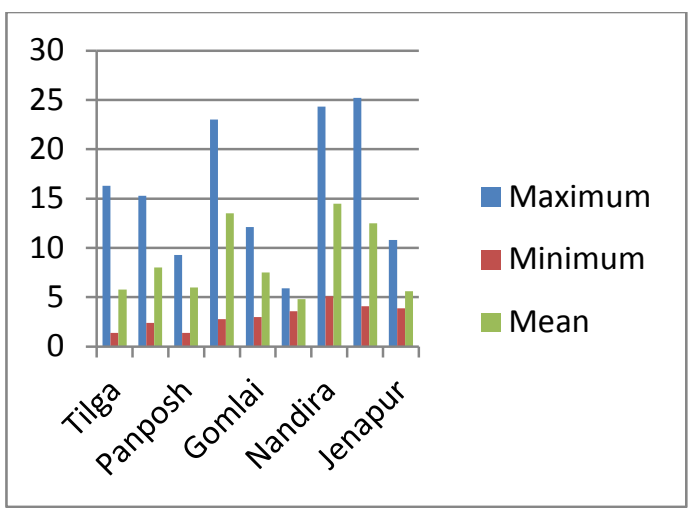

Figure 12:- Total Solids

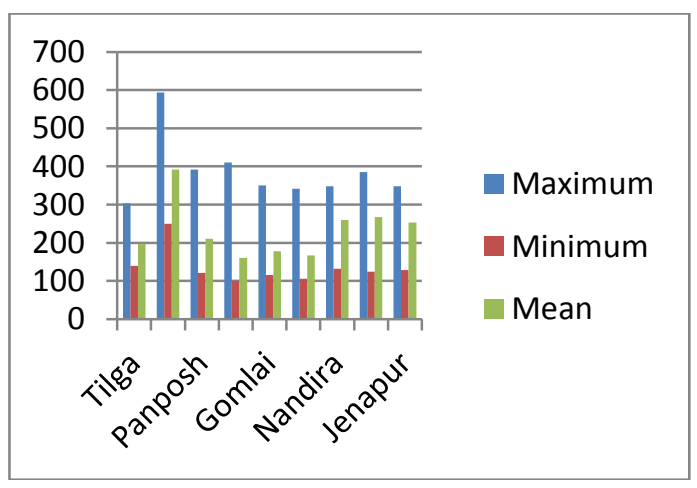

Figure 14:- B.O.D in mg/L

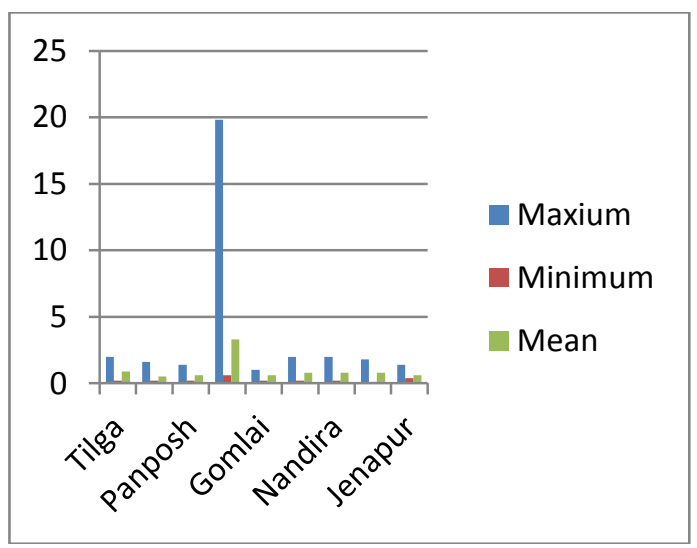

\section{Conclusion}

The present study reveals that the water quality of Brahmani river is quite safe as compared to the physicochemical parameters point of view. However, due to increased industrial and human activities along its bank a constant monitoring of the water quality of the river is a must to maintain the river water quality.

\section{Applications}

The present study is useful in ascertaining the water quality of Brahmani river along its entire stretch for its potability for industrial, agricultural and human use.

\section{References}


[1] APHA, AWWA, WPCF, 2005. Standard Methods for the examination of water and waste waters, $17^{\text {th }}$ ed. American Public Health Association, Washington D.C.

[2] Bhattacharya A.K., S. Basack and P. Maity, 2008. Saline water intrusion in Bhadrak and Balasore district of Orissa, India, EJGE, 13, 01-07.

[3] Goel R.K., 1984. Chemical and Biological methods for water pollution studies.

[4] Henery G.J. and G.W. Heinke, 2005, Environmental Science Engineering ( $2^{\text {nd }}$ Edition), Prentice Hall of India Pvt. Ltd., New Delhi.

[5] Public health service drinking water standards, 1962. Rockville, MD, US Department of Health, Education and Welfare, P-21 ( Public Health Service Publication No. 956 ).

[6] Samantaray Pradyusa, Basant K. Mishra, Chitta. R. Panda and Swoyam P. Rout, 2009. Assessment of water quality index in Mahanadi and Atharabanki rivers and Taladanda canal in Paradip area, India, J. Hum. Ecol. 26(3) 153-161.

[7] Satyanarayan U., 2004. Biochemistry, Books and Allied (P) Ltd, P-455.

[8] Singh B.C. and U.K.Mohapatra, 1998. Physico-chemical and Bacteriological Parameters in various sources of Drinking water in the old Capital City of Cuttack, , J.T.R. Chem.5(1) 44-50.

[9] Webber Jr. W.J. and W. Stamm, 1963. Mechanism of hydrogen ion buffering in natural waters 102 water, Journal of American Water Works Association, $55 ; 1553$.

[10] WHO, 1984, Guidelines for drinking water quality, Vol-3 Geneva. 